\title{
PENGARUH JUMLAH WAJIB PAJAK TERDAFTAR, TINGKAT KEPATUHAN MENYAMPAIKAN SPT DAN PEMERIKSAAN PAJAK TERHADAP PENERIMAAN PAJAK PENGHASILAN PADA KPP PRATAMA TEGAL
}

\author{
Meida Nurul Azizah, Sumarno, dan Abdulloh Mubarok \\ Program Studi Akuntansi \\ Fakultas Ekonomi Universitas Pancasakti
}

\begin{abstract}
The effect of the number of registered taxpayers, compliance level in delivering SPT and tax audits to income tax receipts in Tegal Tax Service Office. Faculty of Economic and Bussines University Of Pancasakti Tegal 2018. The purpose of this research was to determine the effect of the number of registered taxpayers, compliance level in delivering SPT and tax audits to income tax receipts in Tegal Tax Service Office. The data analysis technique used for this research is descriptive and quantitative approach. The research used secondary data and more focused on the realization statements Number of registered taxpayers, compliance level in delivering SPT, tax audits and income tax receipts research sample that is the period of 2015-2017. The data collected were processed using SPSS software program. The statistical method used to test the hypothesis is multiple linier regression analysis. The result showed that the number of registered taxpayers has a positive and significant impact on income tax receipts. However compliance level in delivering SPT and tax audits not impact on income tax receipts.
\end{abstract}

Keywords : Income tax receipts, The number of registered taxpayers, Compliance level in delivering SPT and Tax audits.

\section{PENDAHULUAN}

Indonesia merupakan negara yang sedang berkembang dimana dalam beberapa tahun terakhir sedang gencar dalam melakukan pembangunan di berbagai bidang infrastruktur. Berpedoman pada Anggaran Pendapatan dan Belanja Negara (APBN), pemerintah memiliki dua sumber pokok dalam memenuhi penerimaan yaitu sumber dana luar negeri dan sumber dana dalam negeri. Sumber dana dalam negeri itu sendiri berasal dari sektor non pajak serta sektor pajak. Pajak mempunyai peranan yang dominan bagi negara disebabkan karena pajak merupakan salah satu sumber penerimaan terbesar kurang lebih dua pertiga penerimaan negara saat ini bersumber dari pajak (Kastolani dan Ardiyanto, 2017).

Semakin besarnya pengeluaran maka pemerintah semakin menuntut peningkatan penerimaan negara, di mana yang diharapkan berasal dari dalam negeri tanpa harus bergantung terhadap bantuan dan pinjaman. Hal ini yang menjadikan Direktorat Jenderal Pajak melakukan segala upaya untuk dapat memaksimalkan penerimaan pajak (Simamora dan Suryaman, 2015). 
Berdasarkan penerimaan $\mathrm{PPh}$ dari 2013 hingga 2017 menunjukkan bahwa hasil penerimaan pajak penghasilan pada tahun 2016 menuju 2017 mengalami penurunan. Hal ini disebabkan oleh adanya perubahan peraturan perpajakan mengenai besarnya penghasilan tidak kena pajak (PTKP) pada Peraturan Menteri Keuangan No. 122/PMK010/2015 tentang Penyesuaian Besarnya Penghasilan Tidak Kena Pajak (PTKP) yang diikuti dengan Peraturan Direktur Jenderal Pajak nomor PER32/PJ/2015 menjelaskan bahwa tarif PTKP sebesar Rp 36.000.000,- per tahun untuk wajib pajak orang pribadi. Namun pada Peraturan Direktur Jenderal Pajak No. PER-16/PJ/2016, Peraturan Menteri Keuangan yaitu PMK No. 101/PMK.010/2016 dan PMK No. 102/PMK.010/2016 diterangkan bahwa terjadi perubahan pada tarif PTKP yaitu sebesar Rp. 54.000.000,- per tahun untuk wajib pajak orang pribadi.

Keluarnya Peraturan Direktur Jenderal Pajak No. PER-16/PJ/2016, Peraturan Menteri Keuangan yaitu PMK No. 101/PMK.010/2016 dan PMK No. 102/PMK.010/2016 ternyata berdampak pada penerimaan pajak penghasilan pada tahun 2017 yang mengalami penurunan tersebut. Mengingat perannya yang sangat besar dalam penerimaan APBN maka diperlukan upaya dalam meningkatkan kembali penerimaan pajak penghasilan seperti tahun-tahun sebelumnya Wajib pajak memegang peran yang sangat penting dalam kelancaran sistem dan peraturan perundang-undangan perpajakan, menurut pasal 1 ayat (1) Undang-Undang Nomor 28

Tahun 2007 tentang Tata Cara Perpajakan dijelaskan bahwa "wajib pajak ialah orang pribadi atau badan yang menurut ketentuan peraturan perundang-undangan perpajakan ditentukan untuk melakukan kewajiban perpajakan termasuk memungut pajak atau memotong pajak tertentu". Wajib pajak orang pribadi terdaftar adalah individu yang telah memenuhi syarat sebagai wajib pajak dan terdaftar sebagai wajib pajak di Kantor Pelayanan Pajak (Sari, 2015). adanya berbagai fasilitas dan kemudahan juga diharapkan akan lebih banyak wajib pajak yang mendaftarkan diri untuk memperoleh NPWP sehingga target penerimaan pajak terutama pajak penghasilan dapat tercapai dengan baik. Semakin tinggi kesadaran masyarakat dalam mendapatkan NPWP, diharapkan dapat menambah penerimaan negara dari sektor pajak terutama pajak penghasilan (Fitriani, 2013).

Upaya lain dalam peningkatan pajak penghasilan adalah dengan cara menumbuhkan kesadaran wajib pajak untuk patuh dalam menyampaikan pajak terutang. Kepatuhan wajib pajak orang pribadi dalam menyampaikan pajak terutang dapat dilihat dari patuh atau tidaknya wajib pajak orang pribadi tersebut dalam menyampaikan atau melaporkan SPT (Mulyanti dan Sugiharty, 2016).

Hal lain yang tidak kalah penting adalah penegakan hukum yang ketat oleh aparat perpajakan. Penegakan hukum ini salah satunya dapat berupa pemeriksaan, pemeriksaan ini perlu dilakukan untuk menguji kepatuhan serta mendeteksi adanya kecurangan yang mungkin dilakukan oleh wajib pajak dan juga mendorong mereka untuk patuh membayar pajak serta jujur sesuai ketentuan yang berlaku (Herryanto dan Toly, 2013).

Pemeriksaan pajak sendiri dinilai penting karena pada dasarnya pemeriksaan pajak adalah salah satu pencegahan tax evasion di mana pemeriksaan berupaya mencegah tindak kecurangan yang dilakukan oleh wajib pajak dalam 
pelaksanaan kewajiban perpajakannya. Frekuensi pemeriksaan yang dilakukan akan mempengaruhi penerimaan pajak penghasilan. Semakin sering dilakukan pemeriksaan diharapkan mampu untuk meningkatkan penerimaan pajak penghasilan (Kastolani dan Ardiyanto, 2017).

Pemeriksaan pajak bertujuan untuk menguji dan meningkatkan tax compliance seorang wajib pajak dan diharapkan memiliki pengaruh bagi peningkatan pajak penghasilan penerimaan pajak di Kantor Pelayanan Pajak akan meningkat karena timbulnya kepatuhan pajak akibat dari dilakukannya pemeriksaan pajak (Mahendra dan Sukartha, 2014).

Berdasarkan latar belakang tersebut, maka rumusan masalah dalam penelitian ini adalah:

Apakah Jumlah Wajib Pajak Terdaftar, Tingkat Kepatuhan Menyampaikan SPT, dan Pemeriksaan Pajak berpengaruh terhadap Penerimaan Pajak Penghasilan pada Kantor Pelayanan Pajak Pratama Tegal?

Apakah Jumlah Wajib Pajak Terdaftar berpengaruh terhadap Penerimaan Pajak Penghasilan pada Kantor Pelayanan Pajak Pratama Tegal?

Apakah Tingkat Kepatuhan Menyampaikan SPT berpengaruh terhadap Penerimaan Pajak Penghasilan pada Kantor Pelayanan Pajak Pratama Tegal?

Apakah Pemeriksaan Pajak berpengaruh terhadap Penerimaan Pajak Penghasilan pada Kantor Pelayanan Pajak Pratama Tegal?

Dari rumusan masalah tersebut maka disimpulkan tujuan dari penelitian ini adalah sebagai berikut:
Untuk mengetahui pengaruh jumlah wajib pajak terdaftar, tingkat kepatuhan menyampaikan SPT, dan pemeriksaan pajak berpengaruh terhadap penerimaan pajak penghasilan pada Kantor Pelayanan Pajak Pratama di Kota Tegal.

Untuk mengetahui pengaruh jumlah wajib pajak terdaftar berpengaruh terhadap penerimaan pajak penghasilan pada Kantor Pelayanan Pajak Pratama di Kota Tegal.

Untuk mengetahui pengaruh tingkat kepatuhan menyampaikan SPT berpengaruh terhadap penerimaan pajak penghasilan pada Kantor Pelayanan Pajak Pratama di Kota Tegal.

Untuk mengetahui pengaruh pemeriksaan pajak berpengaruh terhadap penerimaan pajak penghasilanpada Kantor Pelayanan Pajak Pratama di Kota Tegal.

\section{KERANGKA PEMIKIRAN DAN HIPOTESIS}

Pengaruh Jumlah Wajib Pajak Terdaftar, Tingkat Kepatuhan Menyampaikan SPT dan Pemeriksaan Pajak Terhadap Penerimaan Pajak Penghasilan

Diperlukan upaya maupun tindakan dari fiskus dalam rangka meningkatkan penerimaan pajak penghasilan. Salah satu yang dapat dilakukan ialah dengan meningkatkan jumlah wajib pajak yang terdaftar. Wajib pajak merupakan orang pribadi maupun badan yang meliputi pembayaran pajak, pemotong pajak, dan pemungut pajak yang memiliki hak serta kewajiban perpajakan sesuai dengan ketentuan peraturan perpajakan yang berlaku (Mardiasmo, 2013:23).

Semakin banyak masyarakat yang sadar untuk segera mendapatkan NPWP 
dan terdaftar sebagai wajib pajak diharapkan dapat meningkatkan penerimaan dalam sektor pajak terutama pada pajak penghasilan. Namun setelah mendapatkan NPWP dan terdaftar menjadi wajib pajak, tidak sedikit masyarakat yang tidak bisa memenuhi kewajiban dalam membayar pajak.Hal tersebut dapat terjadi karena wajib pajak non aktif, bubar, meninggal dunia, dan sebagainya (Fitriani,2013).

Dari penjelasan tersebut maka dapat dikatakan bahwa tingkat kepatuhan menyampaikan SPT juga dapat memberi pengaruh terhadap penerimaan pajak penghasilan. Dasar pemikiran ini adalah karena penyampaian SPT juga merupakan bagian dari kepatuhan wajib pajak dalam memenuhi kewajiban perpajakannya. Semakin patuh wajib pajak dalam menyampaikan SPT maka semakin meningkat pula penerimaan yang didapat pada sektor pajak penghasilan. Karena dengan taat dalam penyampaian SPT tersebut, artinya wajib pajak juga secara tidak langsung dapat dikatakan telah taat dalam kewajiban perpajakannya (Mulyanti dan Sugiharty, 2016).

Surat pemberitahuan atau SPT itu sendiri merupakan surat yang digunakan oleh wajib pajak untuk melaporkan penghitungan maupun pembayaran pajak, objek pajak, harta serta kewajiban sesuai dengan undang-undang perpajakan. Fungsi darisurat pemberitahuan yaitu sebagai sarana untuk melaporkan dan mempertanggungjawabkan penghitungan jumlah pajak yang sebenarnya terutang dan untuk melaporkan tentang pembayaran atau pelunasan pajak melaporkan penghasilan yang merupakan objek pajak dan atau bukan objek pajak, melaporkan harta dan kewajiban serta melaporkan pembayaran sesuai dengan ketentuan peraturan perundangundangan perpajakan. Sedangkan batas waktu penyampaian surat pemberitahuan untuk SPT tahunan pajak penghasilan wajib pajak orang pribadi dilaporkan paling lama 3 bulan setelah akhir tahun pajak (Mardiasmo, 2013:31).

Faktor lain yang dapat mempengaruhi penerimaan pajak penghasilan yaitu adanya pemeriksaan pajak yang sudah diatur dalam Undang-Undang Ketentuan Umum Tata Cara Perpajakan No. 36 Tahun 2009 yang menyatakan bahwa pemeriksaan adalah serangkaian kegiatan menghimpun dan mengolah data keterangan dan atau bukti yang dilakukan secara objektif dan profesional berdasarkan suatu standar pemeriksaan untuk menguji kepatuhan pemenuhan kewajiban perpajakan dan atau untuk tujuan lain dalam rangka melaksanakan ketentuan peraturan perundangundangan perpajakan.

Pemeriksaan ini perlu dilakukan untuk menguji kepatuhan serta mendeteksi adanya kecurangan yang mungkin dilakukan oleh wajib pajak dan juga mendorong mereka untuk patuh membayar pajak serta jujur sesuai ketentuan yang berlaku. Dengan dilaksanakannya kegiatan pemeriksaan ini oleh pihak fiskus diharapkan dapat memberikan kesadaran dan meningkatkan kepatuhan wajib pajak yang tidak memenuhi kewajiban perpajakannya untuk segera melaksanakan kewajibannya (Hudany, 2015).

H1. Diduga terdapat pengaruh dari jumlah wajib pajak terdaftar, tingkat kepatuhan dalam menyampaikan SPT dan pemeriksaan pajak terhadap Penerimaan Pajak Penghasilan.

\section{Pengaruh Jumlah Wajib Pajak Terdaftar Terhadap Penerimaan Pajak Penghasilan}

Wajib pajak merupakan orang pribadi maupun badan yang meliputi 
pembayar pajak, pemotong pajak, dan pemungut pajak, yang memiliki hak serta kewajiban perpajakan sesuai dengan ketentuan undang-undang perpajakan. Jumlah wajib pajak terdaftar (Fitriani, 2013).

Pentingnya peran wajib pajak terhadap kelancaran sistem serta penerimaan pajak penghasilan maka diperlukan upaya dalam meningkatkan jumlah wajib pajak terdaftar tersebut. Salah satu caranya yaitu dengan menerapkan fasilitas sunset policy yang dapat mempengaruhi serta meningkatkan jumlah wajib pajak dan bertujuan agar dapat menambah orang pribadi maupun badan mendaftarkan diri sebagai wajib pajak (Fitriani, 2013)

Penelitian Fitriani (2013) menyimpulkan bahwa jumlah wajib pajak berpengaruh positif terhadap penerimaan pajak penghasilan. Hal ini disebabkan oleh tingginya jumlah wajib pajak terdaftar yang juga berpengaruh terhadap kenaikan penerimaan penghasilan itu sendiri.

Mendasarkan penjelasan diatas dapat disimpulkan bahwa jumlah wajib pajak terdaftar berpengaruh terhadap penerimaan pajak penghasilan.Hal ini berarti bahwa semakin tinggi jumlah wajib pajak terdaftar, semakin tinggi pula penerimaan pajak penghasilannya (Sari, 2015).

H2. Diduga terdapat pengaruh dari jumlah wajib pajak terdaftar terhadap Penerimaan Pajak Penghasilan

\section{Pengaruh Tingkat Kepatuhan Menyampaikan SPT Terhadap Penerimaan Pajak Penghasilan}

Kepatuhan wajib pajak merupakan suatu kondisi yang menunjukkan wajib pajak dalam memenuhi kewajiban perpajakan dan menjalankan hak dan kewajibannya mengenai perpajakan berdasarkan undang-undang yang berlaku tanpa harus diterapkannya pemeriksaan, peringatan, ataupun ancaman (Darmayani dan Hernianti, 2017)

Patuh atau tidaknya wajib pajak orang pribadi dalam menyampaikan atau melaporkan SPT dapat diketahui dari kepatuhannya dalam menyampaikan pajak terutang. Surat Pemberitahuan (SPT) berdasarkan Undang-Undang Republik Indonesia No. 28 Tahun 2007 yang menguraikan tentang Ketentuan Umum dan tata Cara Perpajakan merupakan surat yang digunakan oleh wajib pajak dalam melaporkan perhitungan dan/atau pembayaran pajak, objek pajak, dan/atau bukan objek pajak, dan/atau harta serta kewajiban berdasarkan ketentuan peraturan perpajakan (Darmayani dan Herianti, 2017).

Kepatuhan seorang wajib pajak dalam menyampaikan SPT tentunya berpengaruh dalam peningkatan penerimaan pajak penghasilan. Hal tersebut dapat terjadi jika seorang wajib pajak dalam menyampaikan SPT dapat sesuai dengan peraturan yang berlaku, yaitu dengan menyampaikan SPT paling lama tiga bulan setelah akhir tahun pajak (Mardiasmo, 2013:31).

Dalam penelitian yang telah dilakukan oleh Mulyanti dan Sugiharty (2016) mengemukakan bahwa tidak terdapat pengaruh yang signifikan pada tingkat kepatuhan menyampaikan SPT terhadap penerimaan pajak penghasilan. Maka dari itu peneliti perlu meneliti kembali untuk membuktikan apakah benar bahwa tingkat kepatuhan menyampaikan SPT tidak berpengaruh terhadap penerimaan pajak penghasilan (Mulyanti \& Sugiharty (2016). 


\section{H3. Diduga terdapat pengaruh dari tingkat kepatuhan menyampaikan SPT terhadap Penerimaan Pajak Penghasilan. \\ Pengaruh Pemeriksaan Pajak \\ Terhadap Penerimaan Pajak Penghasilan}

Pemeriksaan adalah serangkaian kegiatan yang bertujan untuk menguji kepatuhan wajib pajak dalam memenuhi kewajiban perpajakannya serta untuk tujuan lain dalam rangka menjalankan peraturan perundang-undangan perpajakan. Pemeriksaan pajak dilakukan dengan cara mencari, menghimpun, ataupun mengolah suatu data (Mardiasmo, 2013: 52).

Pemeriksaan penting dilakukan karena pemeriksaan merupakan satu dari beberapa cara untuk mencegah adanya tax evasion. Hal itu dilakukan dengan tujuan mencegah agar dalam pelaksanaan kewajiban perpajakannya, wajib pajak tidak melakukan tindak kecurangan. Pemeriksaan pajak juga dapat digunakan untuk meningkatkan kepatuhan pajak dalam diri seorang wajib pajak (Mahendra dan Sukartha, 2014).

Hasil pengujian yang dilakukan oleh Herryanto dan Toly (2013) menguraikan bahwa pemeriksaan pajak berpengaruh terhadap penerimaan pajak penghasilan, namun berbeda dengan yang dikemukakan oleh Hudany (2015) yaitu pemeriksaan pajak tidak berpengaruh terhadap penerimaan pajak penghasilan. Dengan adanya perbedaan tersebut maka perlu dilakukan penelitian kembali terkait pemeriksaan pajak tersebut.

Berdasarkan uraian yang telah dijelaskan, maka dapat ditarik kesimpulan bahwa dilakukannya pemeriksaan pajak dapat mempengaruhi penerimaan pajak penghasilan. Karena semakin sering dilakukannya pemeriksaan, maka semakin tinggi pula tingkat kepatuhan seorang wajib pajak dalam menyampaikan SPT dan hal itu berdampak pula pada peningkatan penerimaan pajak penghasilan.

H4. Diduga terdapat pengaruh dari pemeriksaan pajak terhadap Penerimaan Pajak Penghasilan.

\section{Kerangka Pemikiran}

Dari uraian diatas, maka dapat dibuat kerangka pemikiran sebagai berikut:

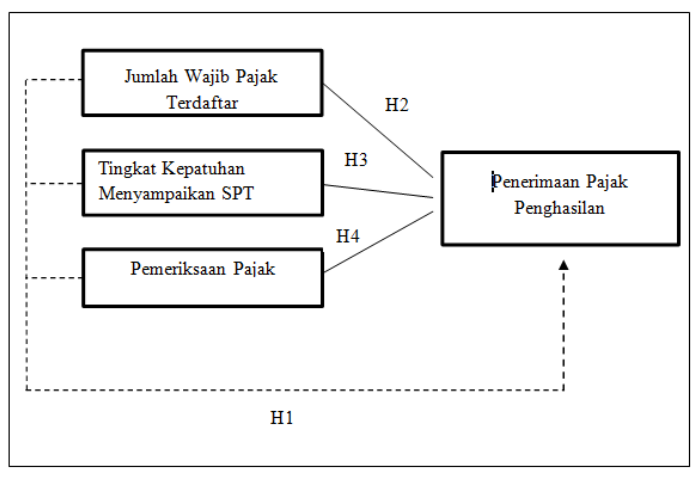

\section{METODE PENELITIAN}

Penelitian ini dilakukan dengan menggunakan metode deskriptif serta pendekatan kuantitatif. Dan menggunakan data sekunder berupa data runtut (time series) dalam bentuk Laporan Perpajakan yang menitikberatkan pada jumlah wajib pajak terdaftar, pemeriksaan pajak, serta tingkat kepatuhan dalam menyampaikan SPT. Dalam penelitian ini data yang digunakan adalah data bulanan selama periode 2015-2017.

Penelitian ini akan dilakukan di Kantor Pelayanan Pajak Pratama Kota Tegal yang berlokasi di Jalan Kolonel Soegiono No. 5 Pekauman, Tegal Barat, Kota Tegal. Populasi dalam penelitian ini adalah Wajib Pajak Orang Pribadi yang terdaftar di KPP Pratama Kota Tegal untuk periode 2015 sampai dengan 
2017. Sedangkan sampel yang digunakan pada penelitian ini ialah seluruh anggota populasi, yaitu Wajib Pajak Orang Pribadi yang terdaftar di KPP Pratama Kota Tegal untuk periode 2015 sampai dengan 2017.

Teknik pengambilan sampel yang digunakan dalam penelitian ini ialah teknik sampling jenuh. Data penelitian ini berupa time series dalam kurun waktu 2015 -2017 dengan data bulanan maka jumlah sampelnya 36 pengamatan. Definisi Operasional Variabel

Variabel Dependen

Variabel dependen dalam penelitian ini adalah penerimaan pajak penghasilan. Penerimaan pajak penghasilan adalah jumlah penerimaan per bulan dari Pajak Penghasilan di KPP Pratama Tegal, data selama 60 bulan terhitung Januari 2015 sampai dengan Desember 2017.

Variabel Independen

Variabel independen dalam penelitian ini meliputi jumlah wajib pajak terdaftar, pemeriksaan pajak dan tingkat kepatuhan dalam menyampaikan SPT.

Jumlah Wajib Pajak Terdaftar

Jumlah wajib pajak terdaftar merupakan laporan realisasi jumlah wajib pajak terdaftar yang keluarkan oleh KPP Pratama Kota Tegal dalam kurun waktu dari tahun 2015 sampai dengan 2017.

\section{Pemeriksaan Pajak}

Pemeriksaan pajak adalah jumlah realisasi Surat Ketetapan Pajak Kurang Bayar (SKPKB) yang diterbitkan oleh KPP Pratama Kota Tegal pada setiap bulannya.
Tingkat Kepatuhan dalam

Menyampaikan SPT

Tingkat kepatuhan dalam menyampaikan SPT adalah jumlah SPT yang dilaporkan oleh KPP Pratama Kota Tegal pada periode 2015 sampai dengan 2017.

Teknik Pengumpulan Data yang digunakan dalam penelitian ini yaitu menggunakan data sekunder yang merupakan data-data yang diperoleh dari KPP Pratama Kota Tegal dari tahun 2015 hingga tahun 2017. Peneliti menggunakan teknik pengumpulan data dengan cara: Teknik Kepustakaan (library
research)

Teknik pengumpulan data dengan mencari buku-buku maupun sumber teori keperpustakaan dan konsep yang relevan untuk menambah teori dalam penelitian ini.

Teknik Dokumentasi

Teknik dokumentasi merupakan teknik pengumpulan data dengan cara melihat data-data yang telah diterbitkan oleh KPP Pratama Kota Tegal dan kemudian dianalisis oleh peneliti.

Teknik pengolahan data yang digunakan dalam penelitian ini adalah program aplikasi Statistical Package for the Social Science (SPSS) versi 22. Dan teknik analisis data yang digunakan dalam penelitian ini adalah analisis regresi linear berganda yang digunakan untuk menguji pengaruh dua variabel atau lebih variabel independen terhadap variabel dependen.

Sebelum melakukan analisis data, terlebih dahulu data diuji dengan pengujian asumsi klasik yang bertujuan untuk dapat memperoleh 
model regresi yang baik. Pengujian asumsi klasik yang dilakukan meliputi uji normalitas data, uji multikolinearitas, uji heterokedastisitas dan uji autokorelasi. Setelah model regresi memenuhi semua asumsi klasik, maka baru dilakukan uji simultan dan uji parsial.

\section{HASIL}

\section{Uji Regresi Linear Berganda}

Tabel 1. Hasil Uji Regresi Linier Berganda

\section{Coefficientsa}

\begin{tabular}{|c|c|c|}
\hline \multirow[t]{2}{*}{ Model } & \multicolumn{2}{|c|}{ Unstandardized Coefficients } \\
\hline & B & Std. Error \\
\hline & 2129211785,466 & 5084825234,687 \\
\hline $\begin{array}{ll}1 & \text { (Constant) } \\
& \end{array}$ & 413020,043 & 159334,411 \\
\hline SPT dilaporkan & 260727,878 & 929796,699 \\
\hline Pemeriksaan & $-22346895,292$ & 23490300,347 \\
\hline
\end{tabular}

Tabel 1 menunjukkan hasil pengujian regresi linear berganda yang menunjukkan koefisien setiap variabel. Dari tabel tersebut dapat dilihat bahwa koefisien untuk variabel jumlah wajib pajak terdaftar bernilai positif sebesar 413.020,043 dengan nilai signifikansi 0,014 menyatakan bahwa variabel jumlah wajib pajak terdaftar berpengaruh positif terhadap penerimaan pajak penghasilan. Koefisien regresi jumlah SPT yang dilaporkan sebesar 260.727,878 dengan signifikansi 0,781 yang menyatakan bahwa variabel jumlah SPT yang dilaporkan tidak berpengaruh terhadap penerimaan pajak penghasilan Koefisien regresi jumlah SPT yang dilaporkan sebesar 260.727,878 dengan signifikansi 0,781 yang menyatakan bahwa variabel jumlah SPT yang dilaporkan tidak berpengaruh terhadap penerimaan pajak penghasilan. Dan koefisien regresi pemeriksaan pajak sebesar -22.346.895,292 dengan signifikansi 0,349 yang menyatakan bahwa variabel pemeriksaan pajak berpengaruh negatif terhadap penerimaan pajak penghasilan.

\section{Uji Pengaruh Simultan (F test)}

Tabel 2. Hasil Uji Pengaruh Simultan (F test).

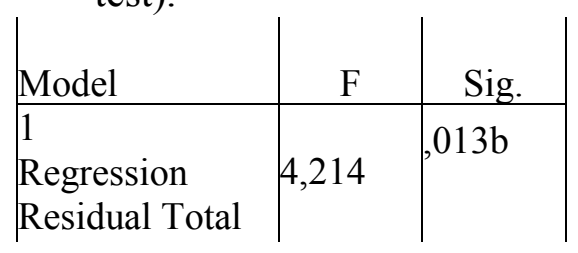

Disimpulkan bahwa didapat nilai $\mathrm{F}$ hitung sebesar 4,214 satuan dengan probabilitas 0,013 satuan. Karena probabilitas lebih kecil dari 0,05 maka model regresi dapat digunakan untuk memprediksi variabel penerimaan pajak penghasilan. Atau dengan kata lain $\mathrm{H} 1$ diterima, yang artinya variabel jumlah wajib pajak terdaftar, tingkat kepatuhan menyampaikan SPT dan pemeriksaan pajak berpengaruh secara simultan terhadap penerimaan pajak penghasilan.

Uji Parsial (t test)

Tabel 3. Hasil Uji Parsial ( $\mathrm{t}$ test)

\begin{tabular}{|c|c|c|}
\hline \multirow{3}{*}{ 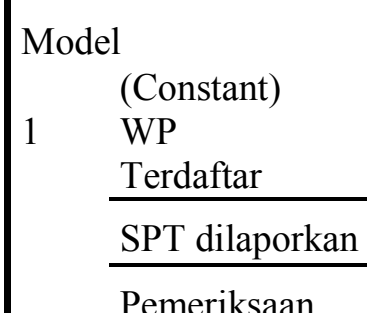 } & $\begin{array}{l}\text { T } \\
, 419 \\
2,592\end{array}$ & $\begin{array}{l}\text { Sig. } \\
\quad 678 \\
\quad 014\end{array}$ \\
\hline & ,280 & ,781 \\
\hline &,- 951 & ,349 \\
\hline
\end{tabular}

Hasil penelitian tabel 3 dalam kolom sig. terlihat bahwa variabel jumlah WP terdaftar (X1) memiliki nilai signifikasi $0,014<0,05$ maka Hipotesis diterima dan mengandung arti bahwa jumlah wajib pajak terdaftar berpengaruh secara parsial terhadap penerimaan pajak penghasilan. Hasil penelitian tabel dalam kolom sig. terlihat bahwa variabel jumlah SPT dilaporkan (X2) memiliki nilai signifikasi 0,781 > 0,05 maka Hipotesis ditolak dan mengandung arti bahwa jumlah SPT dilaporkan tidak berpengaruh secara 
parsial terhadap penerimaan pajak penghasilan. Hasil penelitian tabel dalam kolom sig. terlihat bahwa variabel pemeriksaan pajak (X3) memiliki nilai signifikasi 0,349 >0,05 maka Hipotesis ditolak dan mengandung arti bahwa pemeriksaan pajak tidak berpengaruh secara parsial terhadap penerimaan pajak penghasilan.

\section{Uji Koefisien Determinasi}

Tabel 4. Hasil Uji Koefisien

Determinasi

Model summarryb

\begin{tabular}{|c|c|}
\hline Model & Adjust R Square \\
\hline 1 & .216 \\
\hline
\end{tabular}

Besarnya adjusted R2 adalah 0,216 satuan atau 21,6\%. Hal ini menunjukan bahwa presentase sumbangan pengaruh variabel independen (jumlah wajib pajak terdaftar, tingkat kepatuhan menyampaikan SPT dan pemeriksaan) terhadap variabel dependen (penerimaan pajak penghasilan) sebesar $21,6 \%$, sedangkan sisanya sebesar 78,4\% (100\% - 21,6\% = $63,8 \%$ ) dipengaruhi atau dijelaskan oleh variabel lain yang tidak dimasukan dalam penelitian ini.

\section{KESIMPULAN DAN SARAN}

\section{Kesimpulan}

Berdasarkan pembahasan yang telah dilakukan sebelumnya, maka dapat ditarik kesimpulan sebagai berikut:

Jumlah wajib pajak terdaftar, tingkat kepatuhan menyampaikan SPT dan pemeriksaan pajak berpengaruh secara signifikan terhadap penerimaan pajak penghasilan.

Jumlah wajib pajak terdaftar berpengaruh secara signifikan terhadap penerimaan pajak penghasilan.

Tingkat kepatuhan menyampaikan SPT tidak berpengaruh secara signifikan terhadap penerimaan pajak penghasilan.
Pemeriksaan tidak berpengaruh secara signifikan terhadap penerimaan pajak penghasilan.

Besarnya adjusted R2 adalah 0,216 satuan atau $21,6 \%$. Hal ini menunjukan bahwa presentase sumbangan pengaruh variabel independen (jumlah wajib pajak terdaftar, tingkat kepatuhan menyampaikan SPT dan pemeriksaan) terhadap variabel dependen (penerimaan pajak penghasilan) sebesar $21,6 \%$, sedangkan sisanya sebesar $78,4 \%(100 \%-21,6 \%=$ $63,8 \%$ ) dipengaruhi atau dijelaskan oleh variabel lain yang tidak Saran dimasukan dalam penelitian ini

Peningkatan jumlah wajib pajak terdaftar telah terbukti secara statistic dapat meningkatkan penerimaan pajak penghasilan, maka Kantor Pelayanan Pajak Pratama Tegal hendaknya mengupayakan agar jumlah wajib pajak terdaftar terus meningkat dari tahun ketahun. Serta dapat dijadikan referensi untuk meningkatkan pelayanan bagi masyarakat luas.

Tidak berpengaruhnya tingkat kepatuhan menyampaikan SPT diakibatkan karena tidak sesuainya jumlah wajib pajak yang menyampaikan SPT dengan jumlah yang telah ditetapkan. Maka hendaknya pihak kantor Pelayanan Pajak Pratama Tegal harus lebih mengupayakan agar SPT yang dilaporkan sama dengan SPT yang telah ditetapkan.

Tidak berpengaruhnya pemeriksaan pajak diakibatkan kurang optimalnya kegiatan pemeriksaan pajak yang dilakukan KPP Pratama Tegal, maka pihak KPP Pratama Tegal diharapkan dapat mengoptimalkan kegiatan 
pemeriksaan tersebut agar dapat meningkatkan penerimaan $\mathrm{PPh}$.

Penelitian selanjutnya agar dapat menambahkan jumlah tahun pajak dan menambah atau mengganti variabel independen yang digunakan dalam penelitian karena semakin banyak data yang digunakan maka akan lebih representatif dan mungkin dapat meneliti beberapa KPP Pratama agar dapat diperbandingkan.

Kesediaan masyarakat umum untuk suka rela mendaftarkan diri sebagai wajib pajak serta kesadaran untuk patuh dalam melaporkan pajaknya demi peningkatan kas negara yang digunakan untuk pembangunan nasional.

\section{DAFTAR PUSTAKA}

Arisandi, Yessi. 2015. "Pengaruh Penambahan Wajib Pajak Badan, Penyampaian SPT Masa PPh Badan, Penerbitan Surat Tagihan Pajak dan Pemeriksaan Pajak Terhadap Penerimaan Pajak Penghasilan Badan”. Jom FEKON, Vol. 2. No. 2, Oktober 2015.

Badan Pusat Statistik (BPS), 2018. Realisasi Penerimaan Negara (Milyar Rupiah) 20072017. Online. https://www.bps.go.id/statictable/2009/02/24/1286/ realisasipenerimaan-negara--milyar-rupiah---2007-2017.html. (8 April 2018)

Darmayani, Diera dan Eva Herianti. 2017. "Pengaruh Tingkat Kepatuhan Wajib Pajak Badan Terhadap Peningkatan Penerimaan Pajak Penghasilan dengan Penagihan Pajak Sebagai Variabel Moderating (Pada KPP Pratama Cilandak Jakarta Selatan)". Jurnal InFestasi. Vol. 13, No. 1, Juni 2017.

Fitriani, Nanik. 2013. "Pengaruh Jumlah Wajib Pajak Terdaftar dan Penerbitan Surat Paksa Terhadap

Penerimaan Pajak Penghasilan Pada KPP Pratama Bantul”. Jurnal Akuntansi. Vol. 1, No. 2, Desember 2013.

Ghozali, Imam. 2016. “Aplikasi Analisis Multivariate dengan Program IBM SPSS 21”. Semarang : Badan Penerbit Undip.

Herryanto, Marisa dan Agus Arianto Toly. 2013. "Pengaruh Kesadaran Wajib Pajak, Kegiatan Sosialisasi Perpajakan, dan Pemeriksaan Pajak Terhadap Penerimaan Pajak Penghasilan di KPP Pratama Surabaya Sawahan". Tax And Accounting Review. Vol. 1, No. 1, April 2013.

Hudany, Reida Wulan. 2015. "Pengaruh Eksistensifikasi Pajak, Kepatuhan Pajak, Pemeriksaan Pajak, Penagihan Pajak dan Surat Paksa Pajak Terhadap Penerimaan Pajak Penghasilan Orang Pribadi di KPP Pratama Solok". Jom FEKON. Vol. 2, No. 2, Oktober 2015.

Irianto, Edi Slamet dkk. (2013). "Pajak Kepemimpinan \& Masa Depan Lintas Generasi”. Online. https://books.google.co.id/. (20 April 2018).

Kastolani, Olivia Jessica dan Moh. Didik Ardiyanto. 2017. "Pengaruh Tingkat Kepatuhan Wajib Pajak dan

Pemeriksaan Terhadap Penerimaan Pajak Penghasilan". Diponegoro Journal of Accounting.Vol. 6, No. 3, 2017, hal : 1-10. 
Mahendra, Putu Putra dan I Made Sukartha. 2014. "Pengaruh Kepatuhan, Pemeriksaan, dan Penagihan Pajak Pada Penerimaan Pajak Penghasilan Badan". E-Jurnal Akuntansi Universitas Udayana. Vol. 9, No. 3, 2014, hal: 633-643.

Mardiasmo. 2013. Perpajakan edisi revisi. Yogyakarta : ANDI.

Mulyanti, Dwinta dan Febby Sry Sugiharty. 2016. "Efektifitas WPOP dan Tingkat Kepatuhan Menyampaikan

SPT Terhadap Penerimaan Pajak Penghasilan”. Ecodemica. Vol. 4, No. 2, September 2016. Pardiat. 2008. Pemeriksaan Pajak. Jakarta : Mitra Wacana Media.

Resmi, Siti. 2003. Perpajakan Teori dan Kasus.Jakarta : Salemba Empat.

Sari, Wielda Permata. 2015. "Pengaruh Kesadaran Wajib Pajak, Kegiatan Sosialisasi Perpajakan, Pemeriksaan Pajak dan Jumlah Wajib Pajak Yang Terdaftar Terhadap Penerimaan Pajak Penghasilan Orang Pribadi di KPP Pratama Pekanbaru Tampan”. Jom FEKON. Vol. 2, No. 2, Oktober 2015.

Sari, Yosi Widia. 2015. "Pengaruh Tingkat Kepatuhan Wajib Pajak Badan, Pemeriksaan Pajak, dan Penagihan Pajak Terhadap Peningkatan Penerimaan Pajak Penghasilan Pada Kantor Pelayanan Pajak Pratama Tampan kota Pekanbaru". Jom FEKON. Vol. 2, No. 2, Oktober 2015.

Sekaran, Uma. 2011. Research Methods for Business. Jakarta : Salemba Empat.

Simamora, Patar dan Deni Suryaman. 2015. "Pengaruh Tingkat Kepatuhan Wajib Pajak Orang Pribadi Terhadap Penerimaan Pajak Penghasilan Orang Pribadi pada KPP Pratama Cibinong”. Jurnal Ilmiah Manajemen Fakultas Ekonomi. Vol. 1, No. 1, 2015, hal: 25-31.

Sugiyono. 2012. Metode Penelitian Bisnis. Bandung : Alfabeta.

Syafruddin dkk. 2017. "Pengaruh Kewajiban Kepemilikan NPWP, Pemeriksaan Pajak dan Penagihan Pajak

Terhadap Penerimaan Pajak Penghasilan”. Jurnal Ekonomi dan Bisnis. Vol. 14, No. 1, April 2017. 